$10-1-2021$

\title{
Applying Heidegger to Case Study Research in the Medical and Social Sciences
}

Patrick Whitehead

Albany State University, patrick.whitehead@Asurams.edu

Follow this and additional works at: https://nsuworks.nova.edu/tqr

Digitalrt of the Health Psychology Commons, Quantitative, Qualitative, Comparative, and Historical

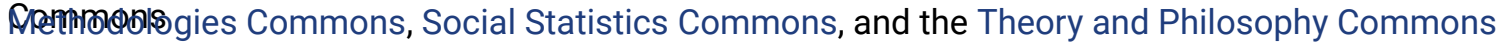
Network

\section{Logo}

Whitehead, P. (2021). Applying Heidegger to Case Study Research in the Medical and Social Sciences. The Qualitative Report, 26(10), 3014-3028. https://doi.org/10.46743/2160-3715/2021.4586

This How To Article is brought to you for free and open access by the The Qualitative Report at NSUWorks. It has been accepted for inclusion in The Qualitative Report by an authorized administrator of NSUWorks. For more information, please contact nsuworks@nova.edu. 


\title{
Qualitative Research Graduate Certificate
}

\section{Applying Heidegger to Case Study Research in the Medical and Social Sciences}

\author{
Abstract \\ In this article, I introduce an approach to the case-study method which is based on the work of German \\ philosopher Martin Heidegger (1889-1976). Heidegger's insights have been applied by philosophers and \\ scholars to the social and health sciences, and this application has increased noticeably over the last \\ decade. This article has been written so that non philosophers may benefit from Heidegger's insights and \\ apply them to their own research and practice. I begin with a description and overview of the shift in \\ perspective that Heidegger has advocated, and how this shift has turned upside down the fields to which \\ it has been applied using formal methods (e.g., object-oriented ontology; Harman, 2018). These fields, \\ however, have primarily been nonhuman, and reveal the hidden depths of ordinary objects. When \\ considering humans, the researcher must search the hidden depths of existence, which includes five \\ interrelated components: embodiment, space, time, relatedness, and mood. Clear and illustrative \\ examples are provided to demonstrate each of these existentials, with one key example drawn on \\ throughout the article.

\section{Keywords} \\ Martin Heidegger, existential phenomenology, phenomenological hermeneutics, qualitative methods, case \\ study methods

\section{Creative Commons License} \\ Creative \\ Commons Ahs work is licensed under a Creative Commons Attribution-Noncommercial-Share Alike 4.0 International \\ Atronse \\ Honcense

\section{A.cknowledgements} \\ Special thanks to Miles Groth for feedback on earlier versions of the article, and for the helpful \\ suggestions and recommendations by journal reviewers and editors.
}




\title{
Applying Heidegger to Case Study Research in the Medical and Social Sciences
}

\author{
Patrick Whitehead \\ Albany State University, Georgia, USA
}

In this article, I introduce an approach to the case-study method which is based on the work of German philosopher Martin Heidegger (1889-1976). Heidegger's insights have been applied by philosophers and scholars to the social and health sciences, and this application has increased noticeably over the last decade. This article has been written so that non philosophers may benefit from Heidegger's insights and apply them to their own research and practice. I begin with a description and overview of the shift in perspective that Heidegger has advocated, and how this shift has turned upside down the fields to which it has been applied using formal methods (e.g., object-oriented ontology; Harman, 2018). These fields, however, have primarily been nonhuman, and reveal the hidden depths of ordinary objects. When considering humans, the researcher must search the hidden depths of existence, which includes five interrelated components: embodiment, space, time, relatedness, and mood. Clear and illustrative examples are provided to demonstrate each of these existentials, with one key example drawn on throughout the article.

Keywords: Martin Heidegger, existential phenomenology, phenomenological hermeneutics, qualitative methods, case study methods

\section{Introduction}

Despite lacking the qualities of generalizability and statistical validity, case studies have played an important role in the human sciences. Take psychology as an example. The rod that pierced the skull of Phineas Gage first illustrated the subtle but consequential function of the frontal cortex and has long served to describe it since (Harlow, 1848). The peculiar psychosomatic disturbances and their treatment in Anna O. have introduced to many generations the principles of psychoanalysis (Breur \& Freud, 1895/1995). And the horrifying education of an infant named Albert demonstrated that the behaviorism of American psychologist John Watson was more than a neat idea (Watson \& Rayner, 1920).

The importance of case studies in the psychological and medical sciences can be seen in the writings of neuropsychiatrist Kurt Goldstein (1963, 2000). Goldstein worked with braininjured soldiers during and after World War II. Along with colleague Adhémar Gelb, Goldstein carefully examined and described the peculiar behavior of his patients so completely that he could anticipate when and how a particular disturbance would occur, such as the in/ability to answer a simple question. Goldstein found that the behavioral disturbances in such unique cases could be useful in understanding human nature more broadly, because the diversity of experiences is narrower in the brain-injured than in the healthy population. French philosopher and admirer of the work of Gelb and Goldstein, Maurice Merleau-Ponty (1942/1962), said the same of studying individual cases of psychopathology.

American psychiatrist Arthur Kleinman (1986) has written an insightful collection of short case studies through which he demonstrates the difference between disease and illness. 
While these can be differentiated briefly in words - diseases are somatic, and illnesses are existential - the concrete examples help illustrate what this difference looks like.

\section{The Promise of Heidegger for Case Study Research}

Heidegger's (1927/2008) contributions to philosophy in the $20^{\text {th }}$ century belong to a class of their own. His fundamental ontology was a departure from the slow-going, stepwise progression in modern science and philosophy from the $17^{\text {th }}$ century onward. Like the glasses resting on the bridge of your nose which you cannot find, Heidegger draws our attention to what has been there all along, but we have forgotten is there ("da" literally "here or there"; Churchill, 2013): existence. The focus on existence requires a significant and consequential shift in focus. What Heidegger calls for in his philosophy is a complete change in understanding of what it means to exist-a question that is often left unanswered (if it is asked at all). Human living, for example, can be defined medically as the presence of a pulse. For Heidegger, however, living cannot be understood by looking at the heart-as-pump. Instead, living is revealed in how the heart is used; the beating heart is the setting thanks to which living becomes possible. The Heidegger-influenced research looks to the living that was made possible.

A Heidegger-influenced change in awareness has been summarized in a simple way by American philosopher Graham Harman (2018), who looks not at human experience but at ordinary objects. Harman translates Heidegger's cumbersome writings to explain how these writings help us understand and avoid problems that come from what Harman calls undermining and over-mining. With under-mining, a laboratory scientist assumes that objects are best understood by first breaking them down into their smallest parts such as atoms or neurons. But the behavior of tiny objects is not always the best way to understand combustion engines or elementary school teachers. With overmining, philosophers and scholars frown at the thought of getting their hands dirty collecting empirical data, and instead explore the immutable truths of the universe by practicing what could be called pure theory. Both approaches - from above and below - miss most of what is there. Harman directs philosophers towards the hidden depths of the things they encounter, and this direction has most recently transformed art and design, most notably architecture (Bedford, 2020; Harman 2019). This way of looking has been aimed at everything from office desks and automobiles (Bogost, 2012; Harman, 2002, 2005) to entities so large that any attempt to understand them forever changes us (Morton, 2013).

The purpose of this article is to encourage a similar change in awareness to reveal the complexity of human being - specifically as it relates to the social sciences and healthcare. I have found a Heideggerian approach helpful in both areas of my research. With psychology, Heidegger has been useful in understanding that humans do not have psychological disorders. "Disorder" is a general category for personal problems (Whitehead, 2019; Whitehead \& Groth, 2019). The category is useful when psychiatry follows the medical model, which relies on, among other things, coding so that insurance companies know when and how to distribute their funds. But each instance of depression, anxiety, or autism occurs as a disruption of a person's daily routine. To understand them, it is necessary to understand the person's daily routine and their expectations about life.

Though Martin Heidegger's (1889-1976) philosophy has seen exciting new applications to understanding lived experience over the past century (Aho, 2018, 2019; Binswanger, 1958; Boss, 1979; Gadamer, 1996; Groth, 2017; Harman, 2002, 2018; Jaspers, 1963; Whitehead, 2019, 2020a), clumsy translations and a general fear of misunderstanding have kept his insights hidden. Because Heidegger is generally categorized as undecipherable, and for this reason, left to only the most ambitious scholars and researchers, the reader might be surprised to learn that his philosophy focuses on the most basic and ordinary of human experiences. These he describes in a way that more closely resembles farmers chatting in a 
corner tavern than graduate students debating in a university classroom. Heidegger should not be reserved for exceptional moments of metaphysical insight, but freely applied to common life events, however mundane. And he should certainly be applied to areas that concern health, disease, well-being, happiness, and so on - areas examined by researchers in medical and social sciences.

\section{A Personal Encounter with Heidegger During a Qualitative Study}

I have felt the need for a Heidegger-based case study method in my own research. When I began conducting qualitative research, I relied on the formal method based on the phenomenology of Edmund Husserl (1859-1938). In this method, which was designed by psychologist Amedeo Giorgi (2009), researchers divide descriptions of experiences into meaning units, divide those units into themes, and examine the themes to determine the structure or essence of the experience. I used Giorgi's descriptive phenomenological method to examine lived experiences in athletes (Senecal \& Whitehead, 2018, 2021; Whitehead, 2019; Whitehead \& Senecal, 2020) and college students (Whitehead \& Wright, 2017). The methodological guidelines of the descriptive phenomenological method were helpful and held me accountable to my data and made sure I had not skimped on any of the steps. Qualitative Journal editors and reviewers were also careful to make sure methods had been followed correctly. But then my interests shifted from Husserl's transcendental phenomenology to Heidegger's existential phenomenology (Whitehead, 2019, 2020a, 2020b; Whitehead \& Groth, 2019). This shift in interest became a problem for me during a study I conducted on postconcussion syndrome (PCS) in athletes of contact sports. One of the participants, who I will call Tyrese, had given a tremendous interview. I felt as if I had stepped into Tyrese's life. I could not bring myself to divide his transcript into meaning units, so I abandoned the Husserlian method and turned to Heidegger. I did not describe PCS as it had been lived by Tyrese. I realized that Husserl was interested in examining the experience whereas Heidegger was interested in examining the person. In other words, PCS was not the star of the show. The star was my participant, Tyrese, who was a large and hulking former linebacker. I described him as they changed over a period of eight years. I described how his relationships changed, his focus changed, and his mood changed, and how all these changes led to a significant priority-change. It is only later that an observer might look on and call what happened "PCS."

There was nothing that prohibited me from using Heidegger's existential phenomenology while following the steps of Giorgi's (2009) Husserlian method but doing so seemed to be in bad faith. I would have been binding myself to an established method only to satisfy journal editors and reviewers. After all, I was not doing descriptive phenomenology; I was doing existential phenomenology of a single participant.

I began looking for a method based in Heidegger that I could use but found little. Hermeneutics and hermeneutic phenomenology, which deal with the kinds of interpreting I was doing in my PCS case study, seemed promising. I found the work of Nancy Moules et al. (2015) and Max van Manen (2018) who encouraged their readers to employ methods with an open mind. Both methods books, however, were careful not to give any guidelines. Reluctance to develop a method using Heidegger probably stems from the belief that methods only ever get in the way - an argument famously made by Heidegger's student Hans Georg Gadamer (1975/2003).

But my experience was that there could be a method to applying Heidegger, provided the researcher worked with a single case. While the method would not provide ordered steps to follow as Giorgi's descriptive phenomenological method had done, the case study approach would specify what to include and where to look. This is what has motivated my present article. 


\section{Thinking in Heidegger}

A final bit of background is necessary before we can discuss Heidegger's approach to case study methodology. For that, we turn to the process of thinking. For Heidegger (2004), there are two types of thinking, which he calls calculative and meditative. By understanding the difference between the two, the reader will understand how Heidegger's approach to hospital patients differs from a conventional medical approach.

Calculative thinking is the kind described by psychologists who use the word "cognition." Synonyms for this kind of thinking may be found in logic, rationality, and memorization. These are what Gestalt psychologist, Max Wertheimer (1959), has called "reproductive thinking," which Wertheimer has explained, is not thinking at all. Take logic, for example. With logic, a set of steps may be followed to solve a problem. If a problem is solved by following the steps, then the soundness of those steps is proven. But it is quite easy to demonstrate how this is not thinking. If I give you directions to the university, and following them, you arrive at the university, then you will trust that the logic of my directions is sound. However, you will not know whether my instructions took you directly to the university, or if I had you drive all around town, passing each of my friends' restaurants and establishments.

Meditative thinking, by comparison, is an openness to new ideas, insights, and intuitions. Heidegger finds in the word, "think," a common root with "thank." When thankful, we are gracious for what we have received. We cannot be thankful for those things we have gone out and taken for ourselves. Consequently, thinking cannot be a procedure for apprehending the knowledge of things. Thinking cannot occur if steps are being followed mindlessly or carelessly. To think, we must open our awareness. It is as English author, George Orwell (1968), has said of writing:

When you think of a concrete object, you think wordlessly, and then, if you want to describe the thing you have been visualizing you probably hunt about until you find the exact words that seem to fit it. When you think of something abstract you are more inclined to use words from the start, and unless you make a conscious effort to prevent it, the existing dialect will come rushing in and do the job for you, at the expense of blurring or even changing your meaning. (p. 138)

With thinking, as in writing, one must always be guarded against short-cuts which hide meaning rather than bringing it out into the open. Heidegger (1927/2008) explains that we cannot describe an experience by following a procedure. There is no paint-by-numbers approach for this. Experience can only ever be demonstrated. In writing, this is the adage that the writer must show instead of tell.

During my research with Tyrese, I realized that the phenomenon in question (PCS) needed to take a back seat to the person whose life had been transformed due to a series of closed-head injuries. The category of disorder comes later, if at all. The point was not that PCS caused unusual outbursts of anger or difficulty focusing; the point was that this former football player was struggling to keep together the life he had worked so hard to build. By adopting a Heideggerian approach, I was free from circling always back to the familiar list of PCS symptoms. It would have been little help to ask, "so it was the headaches that made you angry, right?" In the Heideggerian analysis, it made more sense that fear was responsible for the anger (Whitehead \& Senecal, 2021). 


\section{Applying Heidegger to Case Study Research: How to Do It}

As demonstrated with my PCS study, a Heideggerian approach can be applied to an existing qualitative method. However, doing so will likely require making substantial changes to the method (such as the number of respondents used) and research goal (such as describing a single case instead of the eidetic structure of a phenomenon). You might, like me, decide that too many alterations to a given qualitative method indicates that you have abandoned the method, and it no longer seems fair or honest to explain that you have followed the specific method at all. This is where I recommend choosing a case study design, such as one provided by Hancock and Algozzine (2016) or Yin (2017), and then using the philosophy of Heidegger to inform the processes of interviewing, data analysis, and constructing the narrative.

Any case study manual can be used as a template. There you will find details about how to submit a proposal to an ethical review board, apply for grant funding, research a topic; arrange, conduct, and record interviews; and so on. The application of Heidegger's philosophy will occur throughout these steps.

\section{Choosing a Research Question}

In research dealing with human subjects, such as occurs in the medical and social sciences, the focus is generally on an object. Psychologists study depression, sociologists study gender, and physicians study cancer. The focus of each is on a thing - a what. With Heidegger's approach, the focus is on the person - a who. Who is depressed? Who experiences their gender? Whose anticipated future and self-image have been transformed by the diagnosis of cancer?

Heidegger shows us what it means for a person to exist at one moment, such as being a 72-year-old husband as he's learning about the tumor in his lungs. Medical sociologists can report statistics about how married men 70-80 years-old will generally handle such diagnoses, and these can be helpful for making prognoses. Heidegger asks the researcher to do something different. He asks them to begin with the 72-year-old husband, even as this man struggles to find something to eat that will not make him nauseous. There is more to cancer than an abnormal and pathogenic growth of cells. The cancer impacts this man's identity. This identity (or personality), and how it changes, becomes the focus of the Heidegger-influenced case study researcher.

Therefore, if a researcher is interested in applying Heidegger to their case study research, then the research question must focus on a person, and not some thing or category that this person represents. For example, instead of asking, "What are the effects of medication $m$ on the appetite of elderly patients who are undergoing chemotherapy?" the question might be, "How has Mr. P's relationship to food changed in the wake of the cancer diagnosis and beginning chemotherapy?"

\section{Interviewing}

Once a research participant has been chosen, it is time to hear from them what their experience has been. A common method of obtaining this is interviewing. If you are unfamiliar with the interviewing process, then I recommend reviewing the manuals on case-study research. There you will find advice from planning to transcribing the recordings. But there are some changes that you will be encouraged to make if you are interested in applying Heidegger to the process.

When I came into my first PCS interview as the primary investigator, I was armed with over a decade of clinical studies, diagnostic criteria, and several case studies on the topic. I already had an idea of what to expect. As my interviewee (Tyrese) spoke, I was making a 
checklist of symptoms in my mind. Without realizing it, I was checking to see if Tyrese did, in fact, resemble the diagnosis I was hoping to study. When migraines came up, a light went on inside my head and I interrupted: "Ooh! Tell me more about that." I was gathering descriptive evidence of PCS. I was using Tyrese.

Thankfully, Tyrese was unwilling to be used. (Perhaps it was his training as a linebacker.) He kept circling back to the parts of his experience that confused him - behaviors and feelings that seemed out of the ordinary. He would introduce a story about how he snapped at his girlfriend, and I would think "emotional instability/neuroticism." But he would compare this to earlier stories in his life when he had been patient, kind, and caring stories that he felt more accurately portrayed his personality. I eventually stopped trying to place him into a category, and instead struggled with him to understand the changes that had occurred and were occurring.

It would have been much easier if, from the start, I had had the goal of understanding Tyrese. PCS was just a name for a familiar category into which his experiences might be placed. But before me was a man who was during change, and this change had presented a problem for him. More specifically, had I been following Heidegger's lead during that interview, I would have paid particular attention to five aspects of Tyrese's experience: his awareness of space, time, and body; his relationship to others; and his mood. These are Heidegger's five existentials. They are, for Heidegger, what make humans unique. A summary of these will make up the final step for applying Heidegger to case study research.

\section{Figure 1}

Heidegger's Existentials

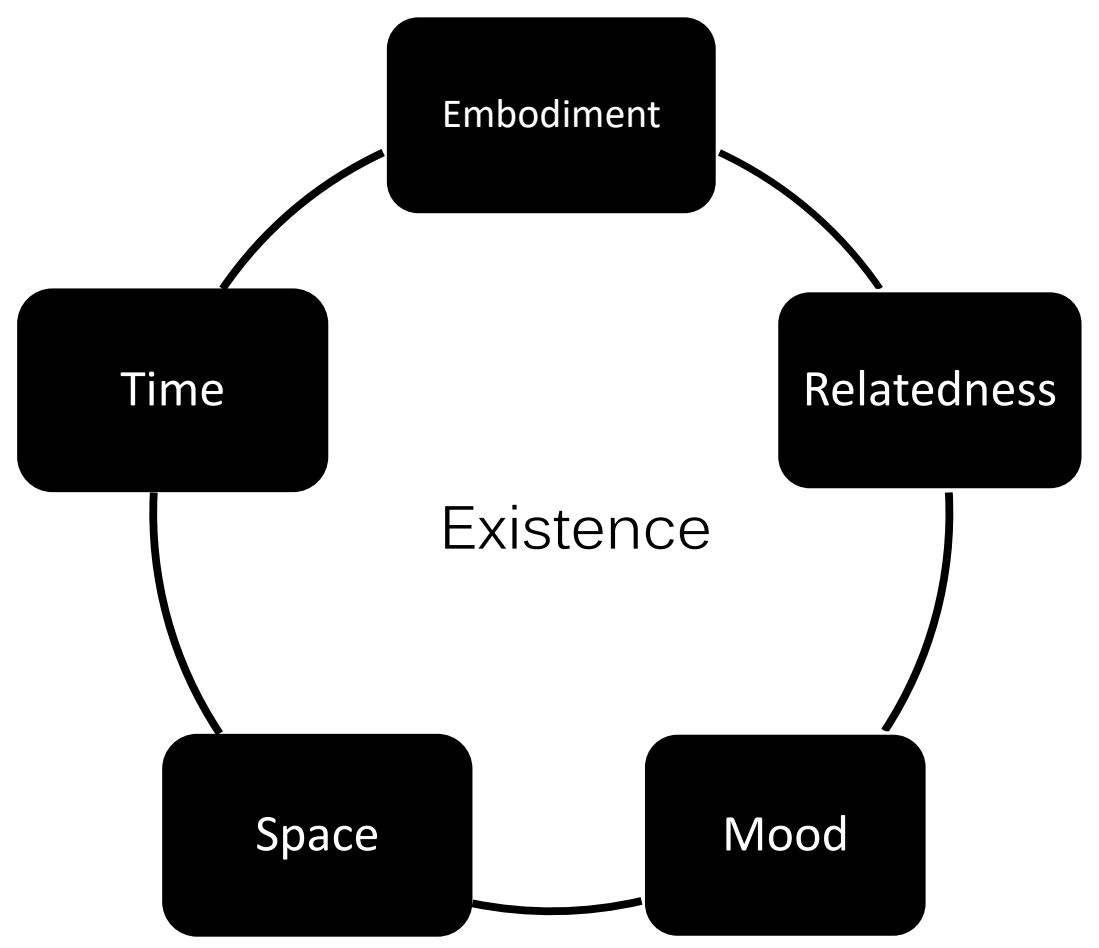

\section{Analyzing the Interview Transcript}

To understand Tyrese through his descriptions of his PCS experience, there is an outline that may be followed. The outline is provided by Heidegger's existentials. When I reviewed my conversation with Tyrese, I learned, for example, that he experienced a significant change in his mood, his relationship with others, and his awareness of time. A change to even one of 
these results in a significant transformation of personality, so it was understandable that Tyrese had trouble in his post-head-injury life.

In what follows, I provide detailed descriptions of each of Heidegger's existentials, and how they might manifest during a case study.

\section{Space}

Space has a familiar definition in modern science. It is presupposed in the definition of mass - that is, the amount of space an object takes up. Space is encountered differently in our experience.

When my wife says that her magazine is on the coffee table, she describes a spatial relationship between magazine and coffee table. With this description, I am directed to the living room where I find that the magazine is merely there on the table. Magazines, however, cannot use coffee tables. The coffee table is only useful for human being. Here the coffee table is suitable for keeping things from falling to the floor where they would be difficult to reach. Magazines do not seek reprieve nor rejoice in their own desirability. They do not exist.

Humans exist; they use coffee tables as surfaces for propping tired feet or collecting magazines. This does not mean that the essence of coffee tables is found in propping up tired human feet or collecting magazines, only that it has qualities useful for these purposes. The usefulness of the coffee table is revealed through human usage.

This is but a toe dipped into space as an existential. To go deeper, we must examine being-in-the-world, where the essence of space is revealed.

Being-in-the-World. "Being-in-the-world" is one of Heidegger's many neologisms. It is unfortunately common for scholars to use neologisms freely, but without fully understanding what they mean. Therefore, I have chosen to take extra time to describe why Heidegger (and his translators) have seen fit to form a train with these words.

Humans are always already in the world, but not in the world the way that coffee is in the coffee cup, or the cup is in my office and so on until we have reached the coffee's placement in the world. Humans are not lumps of carbon-based material strewn about the earth. Wherever they are, humans are always being. Notice the action implied by the word "being." In our world we are surrounded by familiar things. A couch is not a simple object, but an invitation to relax; it is space for resting or ruminating on new case study methods. A couch does not take up space in my office the way it might in a dance hall. In my office, a couch creates space for resting and working.

When Heidegger describes existence as being-in-the-world, he has in mind a kind of thoughtful regard for the places in which we dwell, and the things that make up these dwellings. In my office, I sit comfortably on my couch with my laptop and turn on the lamp above my shoulder. To my right is a wine crate turned on its head which is useful for keeping my coffee out of the way but within reach, and to my left is a stack of books. This arrangement is mine and has been developed over the past decade of sitting for long periods while I work. When my wife stops by to tell me about her day, she observes that there is insufficient natural lighting for plants, and comments that she does not see how I can spend several hours there each day. Notice how in this example my wife and I encounter the same objects but do so in ways that reveal unique aspects of ourselves. Before her comment, it had not occurred to me to consider my office in terms of its suitability for keeping plants. This is not part of my office-world or my world in general. For me, plants are pleasing to look at, but not things to look after or tend to. These are part of my wife's world. There are careful arrangements of plants in front of every window in the house, save the windows in my office which get poor sun. (I understand now why my wife was so willing to let this room be my office!) 
We could imagine still another scenario - a visit from my 8-year-old nephew. How will he be at home in my office? At first there is the novelty of the couch, the armchair, and the thousand or so colorful book-spines. He may strum a few strings on my guitar or thumb through a few books, but finding it all unimaginably dull, he would conclude that my office is unsuitable for being-eight.

As objects in physical space arranged by dimensions of length and width, the office is identical to me, my wife, and my nephew. As things in existential space, however, we find dimensions of ourselves.

Space did not present as a substantial problem for Tyrese, but that does not mean that his awareness of certain spaces did not change. Following concussions, for example, the weight-room was transformed from a comfortable and inviting space to an uncomfortable and foreboding one. Other interviewees from the PCS study described feelings of vertigo when visiting the site of their injury (e.g., mountain climbing gym, hockey arena).

\section{Time}

Given that Heidegger's (1927/2008) most substantial contribution was titled Being and Time, it is obvious that time plays an important role for him. Time, however, only makes sense through human existence. While stop watches and clocks count minutes and seconds, time can only be found in humans.

As it is measured by a watch, time is a standardized unit of duration. While useful for describing and explaining objects in science, this formulation of time has already been abstracted out of and away from where it emerges in humans. Time is only ever "time for..." (fill in the blank). By itself, "five minutes" does not mean anything; it is insignificant or irrelevant. Five minutes is scarcely enough time to prepare eggs, but it might be more than enough time to give directions to the university. Having too much time (boredom) or too little time (anxiety) is a consequence not of the discrete duration (time for what?), but of the horizon of meaning upon which time is being lived (see Aho, 2008, 2019, for a discussion of the temporal quality of mood disorders). I experience six months as too little time when I wish to have already published a book, but too long a time to wait for a vacation.

Humans always exist in a three-fold temporal structure of past, present, and future. Students enter their introductory psychology courses with some knowledge of the field, even if that knowledge consists primarily of misconceptions (Kowalski \& Taylor, 2009). Students still have some idea of what to expect in the classroom and how it will be different from high school. These describe the past, which they bring along. Each student brings a world into the room - that is to say, each student where they are. The students are also directed towards futures which often have to do with getting the celebrated college degree and leveraging it for an impressive job. The past they bring along and the future horizon towards which they work converge upon and give meaning to attending class in the present.

Time extends to all aspects of experience. In thinking, there is the knowledge brought (past), that which is sought after (future), and thinking (present). In research, there is the $a$ priori (past), the answer being sought after (future), and the collection and analysis of data or case studies (present).

For Tyrese, linear passage of time began to break down. This occurred in predictable ways following serious concussions where he blacked out for a period. He would learn afterwards that he was behaving normally, even though he did not remember anything in the hours following the injury. As Tyrese accumulated more and more concussions, he began losing periods of time throughout the day, even when these periods did not immediately follow a head-injury. He described returning from school (high school) one day and being unable to remember anything that happened in his classes. The routines that Tyrese had relied on were 
still in place, but they were no longer useful to him. What good is it to remember to stop at the grocery store on the way home from work when you do not remember why you needed to? Tyrese began to distrust himself, and his grades began to suffer as a result.

\section{Relatedness}

We see already that being-in-the-world also means being-in-time. To this we may now add being-with-Others. We are wrapped up in social relations which shape our existence. When I write a research report, I do not address it to a journal but to the journal's audience. I write for the editor who is a friend and for my colleagues and supervisors who will be evaluating me for promotion. My writing style and focus have been shaped by Others who have served as mentors or have gripped me with their words.

When walking through the grocery store, I am a customer and view the uniformed employees as there on my behalf, willing to help me locate the garam masala. As a sales associate, this person is patient with my ignorance and my requests for their help. As a customer, I am willing to be led across the grocery store by a young person.

When the salesperson asks about an upcoming exam, for a moment I am bewildered. The words have been enunciated clearly, but they seem somehow out of place. My relationship to the salesperson collapses. I am armed with a recipe for curry, not course information. Our relationship is transformed from customer-grocer to teacher-student. I am torn from the occupation as spice-seeker and become instructor, reflecting on a course assignment schedule. In this moment, the horizon of dinner plans recedes and is replaced by the horizon of the fourmonth semester. So, too, does the space of our interaction change. The width of the store aisles is useful for the navigating grocery carts, but less so for answering private questions about grades.

Our existence changes based on the social contexts in which we find ourselves. Upon the horizon of relatedness, space and time are lived differently. I might be giving a lecture on Gestalt theory to 40 students in a classroom when the computer freezes. Immediately I decide to reboot the computer without stopping the lecture and go to the white board to draw the next figure to demonstrate the principle of continuity. All of this occurs to a sea of deadpan faces from which I gather that the students would rather be watching television. This goes on until the computer is back up and running, and I can return to the pre-selected figures which are helpful when it comes to teaching Gestalt principles. Now if the same were to occur in a classroom of 40 potential colleagues who were there to evaluate me for a job or fellowship, then the common technological hiccup would be devastating. Instead of rebooting the computer, I paralyze myself in indecision, scanning my memory for an alternative example or searching the room for something that demonstrates continuity. Here I imagine that the deadpan faces betray disinterest in me as a prospective employee or fellow.

Both settings are objectively identical, right down to the 40 bodies seated about the classroom. But they are not merely bodies, but Others who exist, and who place demands on me. The quality of existence changes everything.

I can choose to ignore another passenger on the elevator. I do this by deliberately looking away from them or shifting my body so as not to indicate interest. I cannot do this with the elevator walls or ceiling. When I ignore a note left by my wife on the kitchen counter, it is not a slip of paper I ignore, but the directive of my wife.

While being-with is particularly apparent during social interactions, this existential structure may also be found in isolation of others - such as when writing an essay alone in my office or running alone on a trail. I cannot write anonymously but must always take up a particular and personal vantage point. Even when authoring an anonymous review on a website, I write as a consumer with all the presumed rights and privileges that pertain. My writing is 
(hopefully) suitable for a particular audience, and my running activity is motivated out of an interest in being validated (by Others) for my fitness or as preparation for a competition (against Others).

In my interview with Tyrese, it was clear that problems in his personal relationships played a significant role in his PCS problem. Over the years, he increasingly felt as though he was unable to be himself around his partners. After a few instances where he surprised himself with angry outbursts, he began taking time away counting to 10, walking away, and so on. When these brief periods were no longer enough, he had to take breaks from his relationships. This led to more and more social isolation, which placed a greater demand on Tyrese's relationships with fellow football players and coaches. It was not surprising to learn that new relationships outside of football played an important part in his recovery.

\section{Mood}

My wife and I have adopted an eight-week-old puppy who has made it her mission to claim each room in the house. Ten minutes ago, she came to a rare stop and collapsed in the middle of the living room floor. I carefully opened my laptop and began revising a paragraph I had written earlier that morning. Alerted by commotion in another corner of the house, the puppy bolted up and out of the living room, followed by me. She found my slipper and began chewing on it. Despite knowledge that anger is confusing to dogs, I aggressively yanked it from her mouth.

If you had pressed me, then I would have tried to explain that this puppy had made me angry. But doing so would have been misleading. Puppies get into trouble. Playful troublemaking belongs to the world of owning puppies. What I found in her activity, however, was frustration. To understand this, we must resist the $a$ causes $b$ formulation. When I began hurriedly revising my paper, I was not attuned to playful troublemaking of puppies. I was resentful of my duties as puppy-parent and tried to shirk these to write. I was also frustrated that my words did not sparkle like those of William James. It was upon these horizons of resentment and frustration that my response to the puppy could be understood. Following her into the hallway, I was receptive to frustrating things - a restless puppy and chewed up slippers. In short, I was already in a frustrated mood, and saw in everything its capacity for frustration.

If my mood had been one of playfulness, then I would have been delighted when she sprang from her nap and would have laughed at the foolishness of having left my slippers out for a teething puppy. Humans do not simply have emotions. They exist through their moods. A hazardous morning commute does not give stress and a poor exam does not make one feel like a failure. In each, a person brings with them a particular kind of mood through which their experience is interpreted.

What stood out to Tyrese as a mood-related problem was not despair or loneliness; Tyrese was concerned about his anger on the football field. He realized that he was no longer a sportsman in competition with others, upholding the integrity of a sport he dominated. Tyrese wanted to kill his opponents. He wanted to hit the running back so hard that they would not be able to stand up. The spirit of the game had been replaced with anger, and that was not the kind of football player he admired. It was not the kind of player he wanted to be.

In the analysis, it was impossible to view Tyrese's anger outside the context of his fear that the next play could be his last. He was playing with a lingering uncertainty about his future. Playing at the highest level of competition requires athletes to be able to give all of themselves. This is difficult for athletes returning from injury, even when their bodies have completely recovered, because there remains the fear of the career-ending play. Physiologically, fear and anger share much in common. Therefore, it is easy to misinterpret fear in dogs as aggressive behavior. Anger was easier than fear to reconcile with his identity as a linebacker. 


\section{Embodiment}

In modern science, objects are considered real only when they take up space (i.e., when they have matter). It is through possession of a body that humans are understood to be real, and this is how human experience is generally handled by the tools of modern science. Seeing is explained by photoreceptors, and touching is explained by corpuscles. Even non-material things are presumed to have a sort of materiality: we see sights, hear sounds, and feel textures (see James, 1904). But a sight cannot be seen outside of seeing any more than a bucket can be said to hold a river (James, 1890).

Our bodies are the ground upon which we encounter things in our world (Boss, 1979; Condrau, 1988). The eyes do not capture sights or cause seeing, but it is through the eyes (and the rest of our body) that we see. When blindfolded, the steps from my bedside to the bathroom suddenly become uncertain. I bump into the bed frame and begin searching for the bathroom doorway well before I have reached it. The objective distances between the things in my bedroom have not changed, but I experience my bed, dresser, and sleeping dog as swollen in size, as if they were suddenly eager to be bumped into or stepped on.

At the home improvement store, I size up the bags of concrete-mix from the perspective I have in my body. If already sore from digging post-holes, the 80-lb bags will look bigger and heavier than when I am well-rested and spry. Objects cannot touch one another. They can bump up against or fall onto one another but cannot reach out or touch. Touching is communicative. Gerontologists, for example, describe the importance of communicative touching when it comes to elder care (Erikson \& Erikson, 1998). Human bodies can be treated like objects, wiped down the way you might wipe down a kitchen counter. This is inadvisable for the treatment of elders, who can also be looked after and cared for. It is also through my body that I hold my wife or wave hello to a passing neighbor.

The nervous system has been a popular focus for inquiry across the behavioral, social, and biological sciences. Even phenomenology (Varela, 1996) and existentialism (Caruso \& Flanagan, 2018) have been paired together with the nervous system. But as we have seen already, behind the phenomenon there is essentially nothing. We will get essentially nowhere with an explanation that experience is caused by the nervous system. Mixing existence with neuroscience is like mixing red and hard; nothing will come of it (Heidegger, 2001; Whitehead, 2020b).

You might be surprised that embodiment is missing from my analysis with Tyrese. After all, I was studying concussions - and concussions happen to the brain. Of course, Tyrese's body was affected by all his concussions, but he did not experience his body as breaking down. Even during recovery following his injures, Tyrese continued lifting weights and training with the team during practices without pads. It was strange to him that he felt normal yet was still unable to give himself completely to his sport (even when the team doctor gave him the green light).

Then, of course, there are the headaches, which must occur in the head, right? What stood out to Tyrese was not the pain, although pain was a factor. Tyrese was unable to focus. He was unable to relax, and unable to sleep. His coping strategies-smart phone, television, music - were closed to him. His headaches could not be separated from the breakdowns in his routine.

\section{Conclusion}

Tyrese's story was a happy one. He was surprised to find support from his friends and mentors even after retiring from football. He took time off from continuing his studies and began working full-time selling football apparel and equipment-tying his pre-injury 
personality to his post-injury personality, which is an important part of rehabilitation. Tyrese made new friends outside of football, which was something he had not previously thought possible. When I interviewed him, Tyrese was already thinking about offering workshops to college and professional football players who had been sidelined by head-injuries.

By itself, the story of Tyrese is as uplifting as it is informative. Any case study approach would be capable of demonstrating this. But where the Heideggerian approach really shines is in how it captures the way Tyrese encountered his injury. PCS is in a state of medical confusion. It has been struck from the DSM-5 (American Psychological Association, 2013), yet remains in the ICD-11 (World Health Organization, 2018). The National Collegiate Athletics Association is divided about whether it is a problem. In other words, it is unpredictable what sort of help Tyrese would be offered by sports medicine or psychiatry. But, after looking at his case through the lens of Heidegger's existentialism, the problems are not only clear-their solutions are clear, too.

Changes to personality occur because of development, injury and illness, and even occupational change. Changes can be seen to my own personality as a qualitative researcher throughout studies such as this one, where my approach to participants, interviews, and analyses undergoes a change considerable enough to require a change in methodology. Tyrese's case can be viewed the same way. We already know that the most significant changes occurred with respect to his relatedness, mood, and awareness of time. A course of treatment would need to focus on each. With relationships, for example, Tyrese would need to adjust his expectations. He wishes to be calm and level-headed, but that has changed. This does not mean that Tyrese must make himself at home with angry outbursts, of course. It means that he must accept that there are certain situations that he must take care to avoid. This is the case with anybody. We build a life for ourselves that emphasizes our strengths and minimizes or hides our weaknesses. There is trouble when we have a misguided view of who we are or what we can handle.

The approach I have described is not a stand-alone method but may be applied to existing methods if the researcher is interested in shining a light on the human person. This is particularly important for those fields where the bright light of modernity has cast a shadow over entire regions of human being such as in the field of clinical psychology, which has increasingly become committed to the neurobiology of psychological suffering (Aho, 2019; American Psychological Association, 2013; Kinderman, 2019). Detailed examples of this can be found in Médard Boss (1979) and Kevin Aho (2019) for psychiatry and clinical psychology; Gion Condrau (1988) or Miles Groth (2017) for psychotherapy; Hans-Georg Gadamer (1996), Kevin Aho (2018) or Arthur Kleinman (1986) for medicine; and my own work (Whitehead, 2019) for health psychology.

\section{References}

Aho, K. (2008). Rethinking the psychopathology of depression. Philosophical Practice, 3(1), 207-218.

Aho, K. (2018). Existential medicine: Essays on health and illness. Rowman \& Littlefield.

Aho, K. (2019). Contexts of suffering: A Heideggerian approach to psychopathology. Rowman \& Littlefield.

American Psychological Association. (2013). Diagnostic and statistical manual of mental disorders $\left(5^{\text {th }} \mathrm{ed}\right)$. APA Press.

Bedford, J. (2020). Is there an object oriented architecture? Engaging Graham Harman. Bloomsbury Academic.

Binswanger, L. (1958). The existential analysis school of thought. In R. May, R. Angel, \& H. F. Ellenberger (Eds.), Existence: A new dimension in psychology and psychiatry (E. 
Angel, Trans., pp. 191-213). Basic Books. (Original work published in German in 1946)

Bogost, I. (2012). Alien phenomenology: Or, what it's like to be a thing. University of Minnesota Press.

Boss, M. (1979). Existential foundations of psychology and medicine. Jason Aronson.

Breuer, J., \& Freud, S. (1995). Studies on hysteria. In J. Strachey (Ed.), The standard edition of the complete psychological works of Sigmund Freud (Vol. 2; pp. 1-335). Hogarth Press.

Caruso, G., \& Flanagan, O. (2018). Neuroexistentialism: Meaning, morals, and purpose in the age of neuroscience. Harvard University Press.

Churchill, S. (2013). Heideggerian pathways through trauma and recovery: "A hermeneutics of facticity." The Humanistic Psychologist, 41(3), 219-230.

Condrau, G. (1988). A seminar on Daseinsanalytic psychotherapy. The Humanistic Psychologist, 16(1), 101-129.

Erikson, E., \& Erikson, J. (1998). The life-cycle completed. W. W. Norton \& Co.

Gadamer, H. (1996). The enigma of health: The art of healing in a scientific age. (J. Gaiger and N. Walker, Trans.). Stanford University Press.

Gadamer, H. G. (2003). Truth and method. (J. Weinsheimer, \& D. G. Marshall, Trans.). Bloomsbury. (Original work published in 1975).

Giorgi, A. (2009). The descriptive phenomenological method in psychology: A modified Husserlian approach. Duquesne University Press.

Goldstein, K. (1963). Human nature in light of psychopathology. Schocken Books.

Goldstein, K. (2000). The organism. ZONE Books.

Groth, M. (2017). After psychotherapy: Essays and thoughts on existential therapy. ENI Press.

Hancock, D. R., \& Algozzine, B. (2016). Doing case study research: A practical guide for beginning researchers $\left(3^{\text {rd }}\right.$ ed.). Teachers College Press.

Harlow, J. M. (1848). Passage of an iron rod through the head. Boston Medical and Surgical Journal, 39(20), 389-393.

Harman, G. (2002). Tool-being: Heidegger and the metaphysics of objects. Open Court.

Harman, G. (2005). Guerilla metaphysics: Phenomenology and the carpentry of things. Open Court.

Harman, G. (2018). Object-oriented ontology: A new theory of everything. Pelican Books.

Harman, G. (2019). Art + objects. Polity.

Heidegger, M. (2001). Zollikon seminars: Letters, conversations, protocols. (F. Mayr, Trans.). Northwestern University Press.

Heidegger, M. (2004). What is called thinking? (J. G. Gray, Trans.). Harper Perennial.

Heidegger, M. (2008). Being and time. (J. MacQuarrie \& E. Robinson, Trans.). Harper Perennial. (Original work published in German in 1927).

James, W. (1890). The principles of psychology (Vol. 1-2). Henry Holt and Company.

James, W. (1904). Does consciousness exist? Journal of Philosophy, Psychology, and Scientific Methods, 1, 477-491.

Jaspers, K. (1963). General psychopathology. University of Chicago Press.

Kinderman, P. (2019). A manifesto for mental health: Why we need a revolution in mental health care. Palgrave Macmillan.

Kowalski, P., \& Taylor, A.K. (2009). The effect of refuting misconceptions in the introductory psychology class. Teaching of Psychology, 36(3), 153-159.

Kleinman, A. (1986). Illness narratives: Suffering, healing, and the human condition. Basic Books.

Merleau-Ponty, M. (1962). Phenomenology of perception (C. Smith, Trans.). Humanities Press. (Original work published in French in 1942). 
Morton, T. (2013). Hyperobjects: Philosophy and ecology after the end of the world. University of Minnesota Press.

Moules, N. J., McCaffrey, G., Laing, C. M., \& Field, J. C. (2015). Conducting hermeneutic research: From philosophy to practice ( $2^{\text {nd }}$ ed.). Peter Lang.

Orwell, G. (1968). Politics and the English language. In S. Orwell \& I. Angos, The collected essays, journalism and letters of George Orwell (Vol. 4, pp. 127-139). Harcourt.

Senecal, G., \& Whitehead, P. M. (2018). Motivational trajectories and well-being in sport: A phenomenological study of running by feel. The Humanistic Psychologist, 46(1), 5373.

Senecal, G., \& Whitehead, P. M. (2021). Social support, identity, and meaning: A phenomenological analysis of post-concussion syndrome. Intech Open: Neurosurgery.

van Manen, M. (2018). Researching lived experience ( $2^{\text {nd }}$ ed.). Routledge.

Varela, F. (1996). Neurophenomenology: A methodological remedy to the hard problem. Journal of Consciousness Studies, 3(4), 330-350.

Watson, J. B., \& Rayner, R. (1920). Conditioned emotional reactions. Journal of Experimental Psychology, 3(1), 1-14.

Wertheimer, M. (1959). Productive thinking. Greenwood Publishing Group.

Whitehead, P. M. (2019). Existential health psychology: The blind-spot in healthcare. Palgrave Macmillan.

Whitehead, P. M. (2020a). Existential biology: Kurt Goldstein's functionalist rendering of the human body. Journal of Consciousness Studies, 49(1-2), 206-224.

Whitehead, P. M. (2020b). Neuroscience cannot reach existence: A Heideggerian critique of neuropsychology. Phainomena, 29(112-113), 159-175.

Whitehead, P. M., \& Groth, M. (2019). Resituating humanistic psychology: Finding meaning in an age of medicalization, digitization, and identity politics. Lexington Books.

Whitehead, P. M., \& Senecal, G. (2020). Balance and mental health in NCAA division I student athletes: An existential-humanistic view. The Humanistic Psychologist, 48(2), 150-163.

Whitehead, P. M., \& Senecal, G. (2021). Falling out of time, relationships, and mood: A case study of post-concussion syndrome. Journal of Phenomenological Psychology [Unpublished manuscript].

Whitehead, P. M., \& Wright, R. (2017). Becoming a college student: An empirical phenomenological analysis of first generation college students. Community College Journal of Research and Practice, 41(10), 639-651.

World Health Organization. (2018). International classification of diseases for mortality and morbidity statistics $\left(11^{\text {th }}\right.$ ed.). World Health Organization.

Yin, R. K. (2017). Case study research and applications: Design and methods (6 ${ }^{\text {th }}$ ed.). Sage.

\section{Author Note}

Patrick is associate professor of psychology and coordinator of general education at Albany State University. He has written five books including Existential Health Psychology: The Blind-spot in Healthcare (2019: Palgrave), and his work has been published in Journal of Phenomenological Psychology and Indo-Pacific Journal of Phenomenology, among others. Please direct correspondence to patrick.whitehead@ Asurams.edu.

Acknowledgements: Special thanks to Miles Groth for feedback on earlier versions of the article, and for the helpful suggestions and recommendations by journal reviewers and editors.

Copyright 2021: Patrick Whitehead and Nova Southeastern University. 


\section{Article Citation}

Whitehead, P. (2021). Applying Heidegger to case study research in the medical and social sciences. The Qualitative Report, 26(10), 3014-3028. https://doi.org/10.46743/2160$3715 / 2021.4586$ 